\title{
Dioctophymatosis as cause of dyspnea in a dog
}

\author{
Maria Ligia de Arruda Mistieri ${ }^{1}$ Susane Werle Dill ${ }^{2}$ Carine Rampelotto ${ }^{3}$ \\ Etiele Maldonado Gomes ${ }^{1^{*}}$ iD João Paulo da Exaltação Pascon ${ }^{4}$ \\ Thaline Segatto $^{5}$ Ingrid Rios Lima Machado ${ }^{2}$
}

${ }^{1}$ Departamento de Clínica Cirúrgica de Pequenos Animais, Universidade Federal do Pampa (UNIPAMPA), CP 118, 97500-970, Uruguaiana, RS, Brasil. E-mail: etielemaldonado@gmail.com. *Corresponding author.

${ }^{2}$ Departamento de Diagnóstico por Imagem, Universidade Federal do Pampa (UNIPAMPA), Uruguaiana, RS, Brasil.

${ }^{3}$ Departamento de Clínica Médica de Pequenos Animais, Universidade Federal de Santa Maria (UFSM), Santa Maria, RS, Brasil.

${ }^{4}$ Departamento de Clínica Médica de Pequenos Animais, Universidade Federal do Pampa (UNIPAMPA), Uruguaiana, RS, Brasil.

${ }^{5}$ Departamento de Anestesiologia Veterinária, Universidade Federal do Pampa (UNIPAMPA), Uruguaiana, RS, Brasil.

ABSTRACT: Dioctophyme renale is a parasite of the nematode class that can infect various species, including humans and dogs. Usually, the parasite migrates to the right kidney of the definitive host. Although, aberrant migrations have been previously reported, they mainly occur without clinical manifestations. No reports of dyspnea secondary to D. renale infestation has been found in the reported literature. The aim of this paper is to report intense respiratory distress caused by the presence of the parasite in the thoracic cavity of a dog. Radiographic images revealed multiple circular structures with a cavity with a radiopaque, thick contour in the thorax, which raised the suspicion of pulmonary bullae. Ultrasound examination revealed nematode infestation in the right kidney, scrotum, and thoracic cavity. Subsequently, right nephrectomy, orchiectomy and trans-sternal thoracotomy were performed to remove the parasites. The patient exhibited recovery after the procedures.

Key words: Dioctophyme renale; dyspnea; thorax; pulmonary bullae.

Dioctofimatose como causa de dispnéia em cão

RESUMO: Dioctophyme renale é um parasita da classe de nematoda que pode infectar diferentes espécies, incluindo humanos e cães. Normalmente, o parasita migra para o rim direito do hospedeiro definitivo. Embora migrações erráticas tenham sido relatadas anteriormente, estas geralmente ocorrem sem manifestações clínicas. Não foram encontrados relatos de dispnéia secundária à infestação de D. renale. $O$ objetivo deste trabalho é relatar a presença do parasita na cavidade torácica de um cão, causando angústia respiratória. As imagens radiográficas revelaram a presença de múltiplas estruturas circulares com aspecto de cavidade e contorno espesso radiopaco no tórax, o que suscitou a suspeita de bullae pulmonar. $O$ exame de ultra-som foi determinante na revelação de infestação múltipla por nematódeos, no rim direito, escroto e cavidade torácica. Posteriormente, como medida terapêutica, foram realizadas os procedimentos de nefrectomia direita, orquiectomia e toracotomia transesternal para remoçãodos parasitas. O paciente evoluiu clinicamente bem após os procedimentos. Palavras-chave: Dioctophyme renale; dispnéia; tórax; bullae pulmonar.

Dioctophyme renale is a parasite of the nematode class with hematophagous habits (MONTEIRO et al., 2002) that can infect various species, for example dogs, cats, and humans (VENKATRAJAIAH et al., 2014). Dogs are considered abnormal definitive hosts and become infected after ingestion of infected paratenic hosts (KOMMERS et al., 1999). The parasite usually affects the right kidney. However, aberrant migrations in dogs have been reported to the abdominal cavity (VEROCAI et al., 2009), scrotum (REGALIN et al., 2016) and urethra (STAINKI et al., 2011), among others. Most often, the discovery of the parasite is incidental, as it rarely causes clinical signs (BUTTI et al., 2016). The aim of this paper is to report the aberrant migration of Dioctophyme renale (D. renale) within the thorax of a dog, causing intense dyspnea.

An approximately one-year-old male dog of no defined breed, weighing $22 \mathrm{~kg}$, was presented at the Veterinary Hospital with acute apathy, anorexia, and dyspnea. During pulmonary auscultation, the presence of discrete crackling was observed. Since the general physical examination did not present any major alterations, the animal 
was referred to the diagnostic imaging section for radiographic chest examination. Right lateral and ventrodorsal radiographs revealed presence of multiple circular structures with a cavity, with a radiopaque thick contour (nine millimeters). The latter measured approximately four centimeters in diameter (Figure 1A), on the caudal portion of the left cranial lobe on laterolateral projection and left caudal lobe, on ventrodorsal projection. A discrete bronchial pattern was reported in the caudal lobes. There was radiographic suspicion of pulmonary bullae.

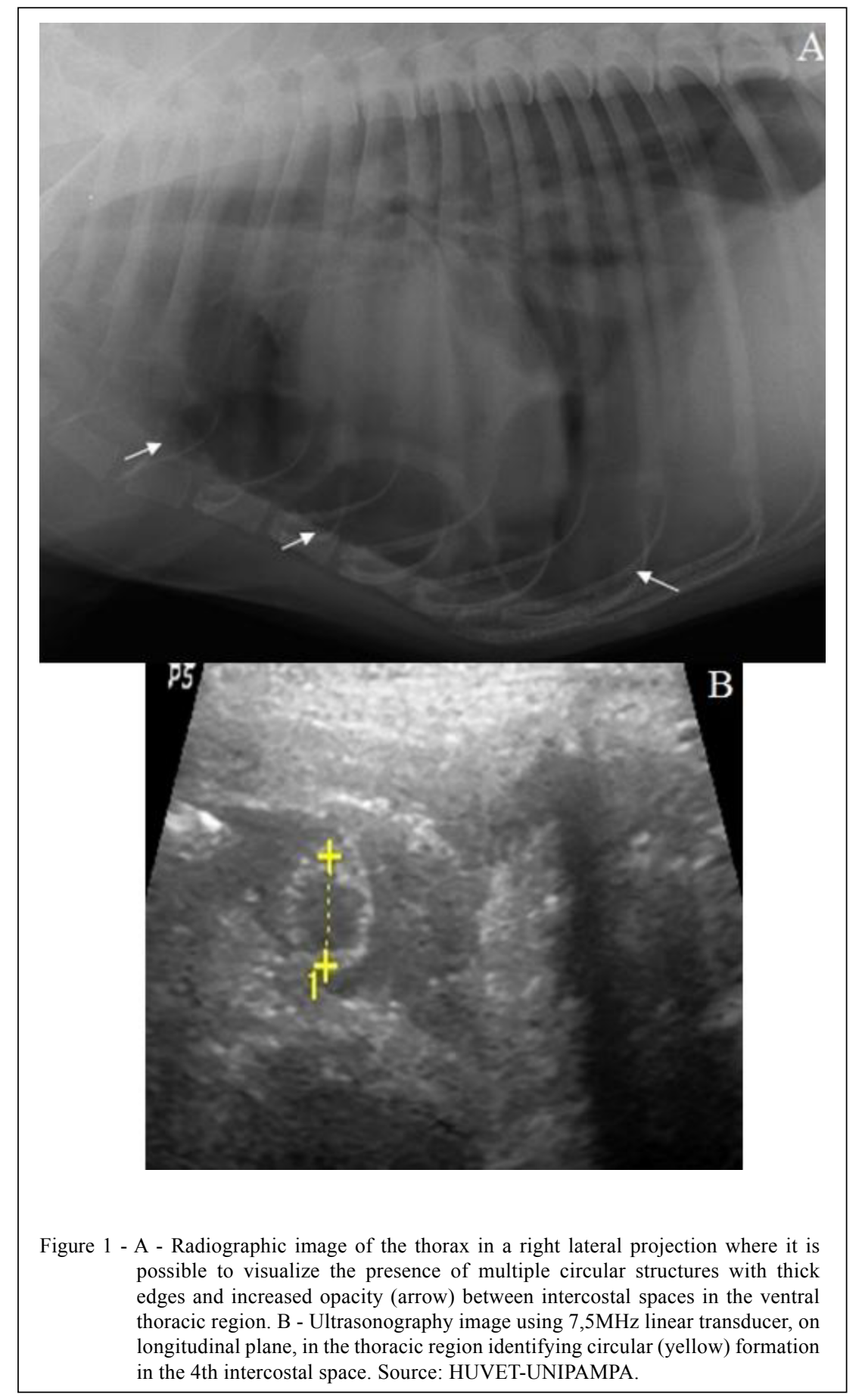

Ciência Rural, v.49, n.1, 2019. 
Oxygen supportive therapy was instituted, and thoracic ultrasonography was performed with the intention of confirming the radiographic suspicion. Ultrasonography examination revealed the presence of tubular structures measuring approximately one centimeter in diameter (Figure 1B), with a hyperechoic interface and mild pleural effusion. Movement was observed in the right and left hemi thorax and in different intercostal spaces in the pleural cavity. Abdominal ultrasound evidenced reduced size of the right kidney in comparison to the left.

The right kidney also presented irregular contours and increased echogenicity in the cortical region. There were also multiple tubular structures of hyperechoic interface in the medulla and renal pelvis, suggesting the presence of nematode parasites. Ultrasound examination of the scrotum showed the presence of mobile circular structures; these images were compatible with the presence of nematode parasites. Thus, a diagnosis of multiple infestation of parasite in the right kidney, scrotum, and thoracic cavity was made. Urinalysis demonstrated the presence of microscopic hematuria with 40-50 red blood cells per high power field, without major alterations.

The animal was referred for the surgical procedures of orchiectomy and trans-sternal thoracotomy to remove the parasite(s). Prior to surgery, the patient received acepram $\left(0.03 \mathrm{mg} \cdot \mathrm{kg}^{-1} \mathrm{IM}\right)$ and morphine $\left(0.5 \mathrm{mg} \cdot \mathrm{kg}^{-1} \mathrm{IM}\right)$. General anesthesia was induced with propofol $\left(2 \mathrm{mg} \cdot \mathrm{kg}^{-1} \mathrm{IV}\right)$ and maintained with isoflurane. Before the surgery, a thoracic drain was positioned and fixed by fingertrap suture in the eighth left intercostal space. Subsequently, a scalpel incision was made in the skin and musculature of the third sternebra till the xiphoid process. The thoracic cavity was evaluated and a free $D$. renale was reported, which was later identified as female with a size of 48 centimeters. Upon removal of the parasite and inspection of the cavity, the presence of moderate pleuritis was observed in the left ventral portion of the thoracic cavity. However, no pulmonary parenchymal lesion was observed, and no pulmonary bullae reported. Thoracic synthesis was then performed by means $0.8 \mathrm{~mm}$ cerclage wire around each sternebra, 3-0 polyglycolic thread in sultan pattern on musculature, a zig-zag pattern with 3-0 polyglycolic thread in the subcutaneous tissue, and nylon 2-0 on the skin with a simple, interrupted pattern. Subsequently, due to the presence of the parasite in the scrotum, orchiectomy was performed through pre-scrotal median access. However, the parasite was not reported at the site and its migration to the abdominal cavity was suspected and synthesis performed. The removal of the abdominal parasites and kidney; however, was left to a future procedure.

The dog was hospitalized for three days to control post-surgical pain (morphine $0.5 \mathrm{mg} \cdot \mathrm{kg}^{-1} \mathrm{SC}$, $\mathrm{q} 12 \mathrm{~h}$; tramadol $2 \mathrm{mg} \cdot \mathrm{kg}^{-1}$ and dipyrone $25 \mathrm{mg} \cdot \mathrm{kg}^{-1}$ both $\mathrm{SC}$, q8h; meloxicam $0.1 \mathrm{mg} \cdot \mathrm{kg}^{-1} \mathrm{SC}, \mathrm{q} 24 \mathrm{~h}$ ), antibiotic therapy (cefalotin $30 \mathrm{mg} \cdot \mathrm{kg}^{-1} \mathrm{SC}$, q8h) and for thoracic drainage. No pneumothorax or postoperative pleural effusion were reported, so the chest drainage was removed two days postoperatively. The animal recovered well clinically, showing no evidence of dyspnea. After two weeks of the first surgical procedure, exploratory celiotomy and right nephrectomy were performed, without major complications. The anesthesia protocol was the same as used in the first surgery. In the same procedure, another free parasite was removed from the abdominal cavity, originated from the migration of $D$. renale previously located in the scrotum. The postoperative protocol was the same as the first surgery, except for morphine, which was not prescribed. After ten days, the dog was discharged from the hospital.

Although, dioctophymosis is generally an accidental diagnosis or necropsy finding (MEYER et al., 2013), some animals may show clinical signs of infestation. Signs of hematuria, anorexia, gait disturbance, emaciation, and apathy have been described previously (BUTTI et al., 2016); however, respiratory distress as a consequence of the presence of $D$. renale, has not been reported. In this case, the animal presented with the clinical manifestation of intense dyspnea secondary to the presence of a free parasite in the thoracic cavity and the consequent inflammation. According to FANTONI \& MASTROCINQUE (2010), respiratory changes, included hypoventilation and hypoxia, and occurred in painful situations. The presence of a free parasite in the thoracic cavity could cause pain, explaining the dyspnea. Another hypothesis is that the clinical signs were secondary to the pleuritis, even though it was not marked on a naked-eye examination. Aberrant migration of $D$. renale into the thoracic cavity is particularly uncommon. Only one report was found in the extant literature describing a necropsy finding, but data on the clinical manifestations of the case were not detailed (MEYER et al., 2013).

Dioctophymatosis can be diagnosed through urinalysis. Although, urinalysis was performed, no significant changes were seen in the exam. The diagnosis can also be reached with the support of imaging tests, such as radiography, ultrasonography and, when available, computed 
tomography (RAHAL et al., 2014). SILVEIRA et al. (2015) emphasize that imaging studies are paramount for the early and definitive diagnosis of parasitism, especially in cases of erratic migration (RAHAL et al., 2014). In this case radiography raised suspicion of pulmonary bullae, a condition caused by alveolar rupture due to small airway obstruction (HAWKINS et al., 2008), characterized radiographically as a large cystic space with thin wall (up to two millimeters) in the lung parenchyma (TAVAKOLI \& MEHRJERDI, 2010). In the present case, the radiographic findings included cystic areas, though the walls were thickened, to approximately nine millimeters. Furthermore, the condition is considered rare in dogs (TAVAKOLI \& MEHRJERDI, 2010) and due to the unusual thickening of the wall of the structure, it was decided that a thoracic ultrasonography should be performed to confirm the suspicion as computed tomography was unavailable. The ultrasonographic examination provided diagnostic confirmation. The technique of thoracic ultrasonography has been explored in recent years to aid in the diagnosis of lung diseases (BABICSAK et al., 2011). Despite its limitations in evaluating lesions below gaseous collections, the technique allowed differentiation between pulmonary and pleural lesions, as well as peripheral pulmonary lesions (SARRAFF-LOPES \& LARSSON, 2011).

In the present case, ultrasonography was able to differentiate the radiographic suspicion of bullae from infestation of the thoracic cavity by $D$. renale. Thus, it was possible to establish a specific and successful therapy for the case.

Currently, there is no option for nonsurgical, drug-based treatment for $D$. renale. Even if the parasite were to lose its viability, it would not be easily eliminated from the body, making surgery the only effective therapy (PEDRASSANI et al., 2009). To date, there is no other report of trans-sternal thoracotomy for removal of the parasite from the thoracic cavity. When available, thoracoscopy is a less invasive option and allows for more detailed exploration (LAKSITO et al., 2010). Although, thoracoscopy was not an option at the hospital where the procedure was performed, the exploratory thoracotomy allowed the appropriate treatment and inspection of the cavity. As described previously in the necropsy findings of MEYER et al (2013), intraoperative evidence of pleuritis was observed. However, no perforations were seen in the pleura, nor was there histopathological confirmation of such alteration.

With the present case report, the aberrant migration of the parasite Dioctophyme renale should be added to the list of differential diagnoses for patients with breathing difficulties in endemic areas. It should also be included as a differential diagnosis in cases suspected of pulmonary bullae. Finally, the thoracic cavity should be considered as a potential locale for the presence of this worm.

\section{BIOETHICS AND BIOSSECURITY COMMITTEE APPROVAL}

We authors of the article entitled "Dioctophymatosis as cause of dyspnea in a dog" declared, for all due purposes, the project that gave rise to the present data of the same has not been submitted for evaluation to the Ethics Committee of the Universidade Federal do Pampa (UNIPAMPA)", but we are aware of the content of the Brazilian resolutions of the National Council for Control of Animal Experimentation (CONCEA) $<$ http://www.mct.gov.br/index.php/content/view/310553.htm> if it involves animals.

Thus, the authors assume full responsibility for the presented data and are available for possible questions, should they be required by the competent authorities.

\section{ACKNOWLEDGEMENTS}

Authors wish to thank Ministério da Educação (MEC) for the scholarship provided to some of the authors.

\section{DECLARATION OF CONFLICTING INTERESTS}

The authors declare no conflict of interest. The founding sponsors had no role in the design of the study; in the collection, analyses, or interpretation of data; in the writing of the manuscript, and in the decision to publish the results.

\section{AUTHORS' CONTRIBUITONS}

MLAM performed the surgical procedure and postoperative care. TS was responsible for the anesthetics procedures. CR and JPEP were responsible for the medical conduct in the first care. SWD and IRLM were responsible for imaging diagnosis. EMG and MLAM were responsible to writing the manuscript. All authors critically revised the manuscript and approved the final version.

\section{REFERENCES}

BABICSAK, V. R. et al. Extracardiac thoracic ultrasonography in small animals. Archives of Veterinary Science, v.16, n.3, p-38-52, 2011. Available from: <http://dxx.doi.org/10.5380/ avs/v16i3.20284>. Accessed: May 11, 2017. doi: 10.5380/avs/ v16i3.20284.

BUTTI, M.J. et al .Dioctophyma renale: Extrarrenal case description in a canine dioctofimosis of Argentina. Neotropical Helminthology, v. 10, n.2, p. 181-187, 2016. Available from: $<$ http://hdl.handle.net/10915/57597>. Accessed: May 8, 2017.

FANTONI, D.T., MASTROCINQUE, S. Fisiopatologia da dor aguda. IN: FANTONI, D.T.; CORTOPASSI, S.R.G. Anestesia em Cães e Gatos. Roca, São Paulo, 2ed, p.524-525, 2010. 
HAWKINS, E.C. Diagnostic tests for the lower respiratory tract. In: NELSON, R. W., COUTO, C.G. Small Animal Internal Medicine. $4^{\text {th }}$ edition, 2008, p. 252-284.

KOMMERS S.G.D.et al. Dioctophymatosis in dogs: 16 cases. Ciência Rural, Santa Maria, v. 29, n. 3, p. 517-522, 1999. Available from: <http://scielo.br/pdf/cr/v29n3/a23v29n3.pdf>. Accessed: Jun. $29,2017$.

LAKSITO, M.A. et al. Thoracoscopic-assisted lung lobectomy in the dog: report of two cases. Australian Veterinary Journal, v. 88, n.7, 2010. Available from: <http://ncbi.nlm.nih.gov/ pubmed/20579032>. Accessed: Jan. 16, 2018. doi: 10.1111/j.17510813.2010.00587.

MEYER, S.N. et al. Finding of Dioctophyme renale in the thoracic cavity of a dog. Revista Veterinária, Corrientes, v. 24, n.1, 2013. Available from: <http://scielo.org.ar/scielo. php? script $=$ sci_arttext\&pid $=$ S 1669-68402013000100014>. Accessed: Mar. 8, 2017.

MONTEIRO, S.G. et al. Natural infection by thirty four helminthes of the dioctophyma renale (GOEZE, 1782) species in a dog. Revista da Faculdade de Zootecnia, Veterinária e Agronomia de Uruguaiana, v. 9, n. 1, p. 95-99, 2002. Available from: <http://revistaseletronicas. pucrs.br/ojs/index.php/fzva/article/viewFile/2149/1658>. Accessed: May 11, 2017.

PEDRASSANI, D. et al. Morphology of eggs of Dioctophyme renale Goeze, 1782 (Nematoda: Dioctophymatidae) and influences of temperature on development of first-stage larvae in the eggs. Revista Brasileira de Parasitologia Veterinária, Jaboticabal, v. 18, n. 1, p. 15-19, 2009. Available from: <http://dx.doi. org/10.4322/rbpv.01801003>. Accessed: May 8, 2017. doi: 10.4322/rbpv.01801003.

RAHAL, S.C. et al. Ultrasonographic, computed tomographic, and operative findings in dogs infested with giant kidney worms (Dioctophyme renale). Journal of the American Veterinary Medical Association, v. 244, n. 5, p. 555-558, 2014. Available from: <https://doi.org/10.2460/javma.244.5.555>. Accessed: May 9, 2017. doi: 10.2460/javma.244.5.555.
REGALIN, B.D.C. et al. Dioctophyma renale em testículo de cão. Acta Scientiae Veterinariae, v.44, 2016. Available from: <http:// revistas.bvs-vet.org.br/actascivet/article/view/31797>. Accessed: Mar. 8, 2017.

SARRAFF-LOPES, A.P., LARSSON, M.H.M.A. Thoracic ultrasonographyc evaluation of dog with pleural and/or pericardial effusion. Brazilian Journal of Veterinary Research and Animal Science, São Paulo, v. 48, n. 5, p. 399-407, 2011. Available from: <http:// dx.doi.org/10.11606/S1413-95962011000500007>. Accessed: Jul. 6, 2017. doi: 10.11606/S1413-95962011000500007.

STAINKI, D.R. et al. Urethral obstruction by Dioctophyma renale in puppy. Comparative Clinical Pathology. v.20, n.5, p. $535-537,2011$. Available from: <https://doi.org/10.1007// s00580-010-1169-0>. Accessed: May 11, 2017. doi: 10.1007// s00580-010-1169-0.

SILVEIRA, C.S. et al. Dioctophyma renale in 28 dogs: clinic pathological and ultrasonographic findings. Pesquisa Veterinária Brasileira, v.35, n.11, p. 899-905, 2015. Available from: <http://dx.doi.org/10.1590/S0100736X2015001100005>. Accessed: May 8, 2017. doi: 10.1590/ S0100-736X2015001100005.

TAVAKOLI, A., MEHRJERDI, K.M. Pulmonary Bulla in a dog secondary to blastomycosis. Iranian Journal of Veterinary Surgery, v. 5, n. 1-2, p.109-114, 2010. Available from: <http://www.ivsajournals.com/article 3149 5bd610edc 48e0278ecf745374e3607f6.pdf $>$. Accessed: Jul. 7, 2017.

VEROCAI, G.G. et al. Dioctophyme renale (Goeze, 1782) in the abdominal cavity of a domestic cat from Brazil. Journal of Veterinary Parasitology, v.12, n.3-4, p. 342-344, 2009. Available from: <https://doi.org/10.1016/j.vetpar.2009.01.032>. Accessed: Jun. 29, 2017. doi: 10.1016/j.vetpar.2009.01.032

VENKATRAJAIAH, N. et al. Dioctophymatosis renalis in humans: first case report from India. Journal of the Association of Physicians of India. v.62, n. 10, p 70-73, 2014. Available from: <http://www.japi.org/october_2014/018 crdioctophymatosis.pdf>. Accessed: Jul. 7, 2017. 